\title{
Poly(lactic acid)/poly(lactic-co-glycolic acid) particulate carriers for pulmonary drug delivery
}

\author{
Fakhrossadat Emami ${ }^{1} \cdot$ Seyed Jamaleddin Mostafavi Yazdi ${ }^{2} \cdot$ Dong Hee $\mathrm{Na}^{3} \mathbb{C}$
}

Received: 6 April 2019 / Accepted: 15 April 2019 / Published online: 22 April 2019

(c) The Author(s) 2019, corrected publication 2019

\begin{abstract}
Background Pulmonary route is an attractive target for both systemic and local drug delivery, with the advantages of a large surface area, rich blood supply, and absence of first-pass metabolism. Numerous polymeric micro/nanoparticles have been designed and studied for controlled and targeted drug delivery to the lung.

Area covered Among the natural and synthetic polymers for polymeric particles, poly(lactic acid) (PLA) and poly(lacticco-glycolic acid) (PLGA) have been widely used for the delivery of anti-cancer agents, anti-inflammatory drugs, vaccines, peptides, and proteins because of their highly biocompatible and biodegradable properties. This review focuses on the characteristics of PLA/PLGA particles as carriers of drugs for efficient delivery to the lung. Furthermore, the manufacturing techniques of the polymeric particles, and their applications for inhalation therapy were discussed.

Expert opinion Compared to other carriers including liposomes, PLA/PLGA particles present a high structural integrity providing enhanced stability, higher drug loading, and prolonged drug release. Adequately designed and engineered polymeric particles can contribute to a desirable pulmonary drug delivery characterized by a sustained drug release, prolonged drug action, reduction in the therapeutic dose, and improved patient compliance.
\end{abstract}

Keywords Poly(lactic acid) $\cdot$ Poly (lactic-co-glycolic acid) $\cdot$ Microparticles $\cdot$ Nanoparticles $\cdot$ Pulmonary drug delivery

\section{Introduction}

Pulmonary drug delivery provides non-invasive method of drug administration with several advantages over the other administration routes. These advantages include large surface area $\left(100 \mathrm{~m}^{2}\right)$, thin $(0.1-0.2 \mathrm{~mm})$ physical barriers for absorption, rich vascularization to provide rapid absorption into blood circulation, absence of extreme $\mathrm{pH}$, avoidance of first-pass metabolism with higher bioavailability, fast systemic delivery from the alveolar region to lung, and less metabolic activity compared to that in the other areas of the body (Ali 2010; Lee et al. 2018; Yu et al. 2016). The local delivery of drugs using inhalers has been a proper

Dong Hee $\mathrm{Na}$

dhna@cau.ac.kr

1 Department of Pharmaceutics, College of Pharmacy, Tehran University of Medical Sciences, Tehran, Iran

2 Department of Mechanical Engineering, Kyungpook National University, Daegu 41566, Republic of Korea

3 College of Pharmacy, Chung-Ang University, 84 Heukseok-ro, Dongjak-gu, Seoul 06974, Republic of Korea choice for most pulmonary diseases (Pison et al. 2006), including asthma (Basheti et al. 2017; Lavorini et al. 2008), cystic fibrosis (Adi et al. 2010; Bilton et al. 2011), chronic obstructive pulmonary disease (COPD) (Schulte et al. 2008; Sulaiman et al. 2017), lung infections (Cipolla and Chan 2013; Golshahi et al. 2011; Oliveira et al. 2017), lung cancer (Zhu et al. 2017), and pulmonary hypertension (Gupta et al. 2011; Kanwar et al. 2016). In addition to the local delivery of drugs, inhalation can also be a good platform for the systemic circulation of drugs (Moroz et al. 2016; Rytting et al. 2008; Thwala et al. 2017). The pulmonary route provides a rapid onset of action even with doses lower than that for oral administration, resulting in less side-effects because of the increased surface area and rich blood vascularization (Ali 2010).

After administration, drug distribution in the lung and retention in the appropriate site of the lung is important to achieve effective treatment (Labiris and Dolovich 2003a). A drug formulation designed for systemic delivery needs to be deposited in the lower parts of the lung to provide optimal bioavailability (Poursina et al. 2016). However, for the local delivery of antibiotics for the treatment of pulmonary 
infection, prolonged drug retention in the lungs is required to achieve proper efficacy. For the efficacy of aerosol medications, several factors including inhaler formulation, breathing operation (inspiratory flow, inspired volume, and endinspiratory breath hold time), and physicochemical stability of the drugs (dry powder, aqueous solution, or suspension with or without propellants), along with particle characteristics, should be considered (Labiris and Dolovich 2003a, b).

Microparticles (MPs) and nanoparticles (NPs), including micelles (Mahajan and Mahajan 2016), liposomes (Bhardwaj et al. 2016), solid lipid NPs (Ji et al. 2016), inorganic particles (Seydoux et al. 2016), and polymeric particles (Oliveira et al. 2017) have been prepared and applied for sustained and/or targeted drug delivery to the lung. Although MPs and NPs were prepared by various natural or synthetic polymers, poly(lactic acid) (PLA) and poly(lactic-co-glycolic acid) (PLGA) particles have been preferably employed owing to their biocompatibility and biodegradability (Kumari et al. 2010; Mohamed and van der Walle 2008; Na et al. 2007). Polymeric particles retained in the lungs can provide high drug concentration and prolonged drug residence time in the lung with minimum drug exposure to the blood circulation (Harush-Frenkel et al. 2010). This review focuses on the characteristics of PLA/PLGA particles as carriers for pulmonary drug delivery, their manufacturing techniques, and their current applications for inhalation therapy.

\section{Polymeric particles for pulmonary delivery}

The preparation and engineering of polymeric carriers for local (Tables 1 and 2) or systemic delivery (Table 3 ) of drugs to the lung is an attractive subject. In order to provide the proper therapeutic efficiency, drug deposition in the lung as well as drug release are required, which are influenced by the design of the carriers and the degradation rate of the polymers (Ali 2010). Different varieties of natural polymers including cyclodextrin, albumin, chitosan, gelatin, alginate, and collagen or synthetic polymers including PLA, PLGA, polyacrylates, and polyanhydrides are extensively used for pulmonary applications (Abdelaziz et al. 2018). Natural polymers often show a relatively short duration of drug release, whereas synthetic polymers are more effective in releasing the drug in a sustained profile from days to several weeks (Rytting et al. 2008). Synthetic hydrophobic polymers are commonly applied in the manufacture of MPs and NPs for the sustained release of inhalable drugs (Abdelaziz et al. 2018; Ungaro et al. 2012).

\section{PLA/PLGA polymeric particles}

PLA and PLGA are the most commonly used synthetic polymers for pharmaceutical applications (Campardelli et al.
2016; Panyam and Labhasetwar 2003). They are approved materials for biomedical applications by the Food and Drug Administration (FDA) and the European Medicine Agency (Campardelli et al. 2016; Ernst et al. 2018). Their unique biocompatibility and versatility make them an excellent carrier of drugs in targeting different diseases (Ernst et al. 2018). The number of commercial products using PLGA or PLA matrices for drug delivery system (DDS) is increasing, and this trend is expected to continue for protein, peptide, and oligonucleotide drugs (Mohamed and van der Walle 2008). In an in vivo environment, the polyester backbone structures of PLA and PLGA go through hydrolysis and produce biocompatible ingredients (glycolic acid and lactic acid) that are eliminated from the human body through the citric acid cycle. The degradation products do not affect normal physiological function. Drug release from the PLGA or PLA particles is controlled by diffusion of the drug through the polymeric matrix and by the erosion of particles due to polymer degradation (Anderson and Shive 1997). PLA/ PLGA particles often show a three-phase drug release profile with an initial burst release, which is adjusted by passive diffusion, followed by a lag phase, and finally a secondary burst release pattern (Amatya et al. 2013; Rytting et al. 2008). The degradation rate of PLA and PLGA is modulated by $\mathrm{pH}$, polymer composition (glycolic/lactic acid ratio), hydrophilicity in the backbone, and average molecular weight; hence, the release pattern of the drug could fluctuate from weeks to months (Alexis 2005; Campardelli et al. 2016). Encapsulation of drugs into PLA/PLGA particles afford a sustained drug release for a long time ranging from 1 week to over a year, and furthermore, the particles protect the labile drugs from degradation before and after administration (Hang et al. 2015). In PLGA MPs for the co-delivery of isoniazid and rifampicin, free drugs were detectable in vivo up to 1 day, whereas MPs showed a sustained drug release of up to 3-6 days (Dutt and Khuller 2001). By hardening the PLGA MPs, a sustained release carrier system of up to 7 weeks in vitro and in vivo could be achieved. This study suggested that PLGA MPs showed a better therapeutic efficiency in tuberculosis infection than that by the free drug.

\section{Large porous microparticles}

Inhalable PLA/PLGA MPs have been widely studied with the aim to find strategies for the prolonged release of drugs in the lung. The inhalable particles need to be small for appropriate lung deposition, but this may result in low drug encapsulation into MPs. The low drug content may require frequent administrations to achieve maximal drug concentration in the lung, which may cause the accumulation of incompletely degraded polymers in the lung and subsequent adverse effects (Abdelaziz et al. 2018). Therefore, 
Table 1 Inhalable poly(lactic acid)/poly(lactic-co-glycolic acid) (PLA/PLGA) microparticles (MPs) for local delivery of drugs to the lung

\begin{tabular}{|c|c|c|c|c|c|c|}
\hline Particles & Drug & Indication & $\begin{array}{l}\text { Preparation Tech- } \\
\text { nique }\end{array}$ & Excipients & $\begin{array}{l}\text { Particle properties } \\
\text { and outcome }\end{array}$ & References \\
\hline $\begin{array}{l}\text { Large porous PLA/ } \\
\text { PLGA MPs }\end{array}$ & Montelukast & Asthma & $\begin{array}{l}\text { Double emulsion- } \\
\text { evaporation } \\
(\mathrm{w} / \mathrm{o} / \mathrm{w})\end{array}$ & PEI-1 & $\begin{array}{l}\text { MMAD: } 1.59- \\
2.51 \mu \mathrm{m} \\
\text { EE:75.7-89.3\% }\end{array}$ & Patel et al. (2017a) \\
\hline PLA MPs & Rifampicin & Pulmonary infection & Electrospray & PEC & $\begin{array}{l}\text { MMAD: } 4-5 \mu \mathrm{m} \\
\text { Sustained release }\end{array}$ & Priemel et al. (2018) \\
\hline $\begin{array}{l}\text { Large porous PLGA } \\
\text { MPs }\end{array}$ & $\begin{array}{l}\text { Montelukast and } \\
\text { heparin }\end{array}$ & Asthma & $\begin{array}{l}\text { Double emulsion- } \\
\text { evaporation }\end{array}$ & PEI & $\begin{array}{l}\text { EE: } 66.8 \% \text { for mon- } \\
\text { telukast } \\
\text { Heparin adsorption } \\
\text { efficiency: } 91.7 \% \\
\text { Sustained drug } \\
\text { release }\end{array}$ & Patel et al. (2017b) \\
\hline $\begin{array}{l}\text { Homogenous PLGA } \\
\text { MPs }\end{array}$ & Rifampicin & Tuberculosis & $\begin{array}{l}\text { Single emulsion- } \\
\text { evaporation }(\mathrm{o} / \mathrm{w}) \\
\text { with glass beads }\end{array}$ & PVA, PEI & $\begin{array}{l}\text { Particle size: } 2-3 \mu \mathrm{m} \\
\text { Sustained release at } \\
7 \text { days }\end{array}$ & Liu et al. (2016) \\
\hline Porous PLGA MPs & $\begin{array}{l}\text { Doxorubicin and } \\
\text { miR-519c }\end{array}$ & Lung cancer & $\begin{array}{l}\text { Double emulsion- } \\
\text { evaporation } \\
\text { (w/o/w) }\end{array}$ & $\begin{array}{l}\text { Ammonium bicar- } \\
\text { bonate }\end{array}$ & $\begin{array}{l}\text { MMAD }<10 \mu \mathrm{m} \\
\text { Sustained release and } \\
\text { good anti-tumor } \\
\text { efficacy }\end{array}$ & Wu et al. (2016) \\
\hline PLA/PLGA MPs & 5-fluorouracil & Lung cancer & Spray drying & - & $\begin{array}{l}\text { Particle size: } \\
1.2-1.5 \mu \mathrm{m}\end{array}$ & Hitzman et al. (2006) \\
\hline $\begin{array}{l}\text { Large porous PLGA } \\
\text { MPs }\end{array}$ & Doxorubicin & $\begin{array}{l}\text { Metastatic lung } \\
\text { cancer }\end{array}$ & $\begin{array}{l}\text { Double emulsion- } \\
\text { evaporation } \\
(\mathrm{w} / \mathrm{o} / \mathrm{w})\end{array}$ & $\begin{array}{l}\text { PEMA, Ammonium } \\
\text { bicarbonate }\end{array}$ & $\begin{array}{l}\text { Particle size: } \\
14.1 \mu \mathrm{m} \\
\text { MMAD: } 3.6 \mu \mathrm{m} \\
\text { Good phagocytosis } \\
\text { escapement } \\
\text { Retention for } 14 \text { days } \\
\text { in mice lung }\end{array}$ & Kim et al. (2012) \\
\hline $\begin{array}{l}\text { Large porous PLGA } \\
\text { MPs }\end{array}$ & $\begin{array}{l}\text { Doxorubicin and } \\
\text { TRAIL }\end{array}$ & $\begin{array}{l}\text { Metastatic lung } \\
\text { cancer }\end{array}$ & $\begin{array}{l}\text { Double emulsion- } \\
\text { evaporation } \\
(\mathrm{w} / \mathrm{o} / \mathrm{w})\end{array}$ & $\begin{array}{l}\text { PEMA, Ammonium } \\
\text { bicarbonate }\end{array}$ & $\begin{array}{l}\text { Particle size: } \\
11.5 \mu \mathrm{m} \\
\text { EE: } 86.5 \% \text { (doxo- } \\
\text { rubicin), } 91.8 \% \\
\text { (TRAIL) } \\
\text { Sustained release in } \\
7 \text { days and reten- } \\
\text { tion for } 7 \text { days in } \\
\text { mice lung } \\
\text { Proper anti-tumor } \\
\text { effect }\end{array}$ & Kim et al. (2013) \\
\hline $\begin{array}{l}\text { Large porous PLGA } \\
\text { MPs }\end{array}$ & Budesonide & Asthma & $\begin{array}{l}\text { Double emulsion- } \\
\text { evaporation } \\
(\mathrm{w} / \mathrm{o} / \mathrm{w})\end{array}$ & $\begin{array}{l}\text { PVA, Ammonium } \\
\text { bicarbonate }\end{array}$ & $\begin{array}{l}\text { Particle size: } \\
\text { 6.4-9.2 } \mu \mathrm{m} \\
\text { MMAD: } 2.5-6.4 \mu \mathrm{m} \\
\text { Density: } 0.7-0.98 \mathrm{~g} / \\
\mathrm{cm}^{3} \\
\text { Pore size: } \\
0.7-1.5 \mu \mathrm{m} \\
\text { EE: } 56-76 \%\end{array}$ & Oh et al. (2011) \\
\hline PLGA MPs & PGE1 & $\begin{array}{l}\text { Pulmonary arterial } \\
\text { hypertension }\end{array}$ & $\begin{array}{l}\text { Double emulsion- } \\
\text { evaporation }\end{array}$ & PVA, PEI & $\begin{array}{l}\text { Particle size: } \\
7-22 \mu \mathrm{m} \\
\text { MMAD: } 2.5-3.5 \mu \mathrm{m} \\
\text { PDI: } 1.5-5.2 \\
\text { Density: } 0.1-0.45 \mathrm{~g} / \\
\mathrm{cm}^{3} \\
\text { FPF: } 50.9-63.2 \% \\
\text { EE: } 61.2-99 \% \\
\text { Bioavailability: } \\
\text { 82-96\% }\end{array}$ & $\begin{array}{l}\text { Gupta and Ahsan } \\
\text { (2011) }\end{array}$ \\
\hline PLA MPs & $\begin{array}{l}\text { Isoniazid and } \\
\text { Rifabutin }\end{array}$ & Tuberculosis & Spray drying & - & $\begin{array}{l}\text { Particle size: } 5 \mu \mathrm{m} \\
\text { MMAD: } 3.6 \mu \mathrm{m} \\
\text { FPF: } 78.9 \% \\
\text { Yield }>60 \%\end{array}$ & Muttil et al. (2007) \\
\hline PLGA MPs & Capreomycin & Tuberculosis & $\begin{array}{l}\text { Solid in o/w solvent } \\
\text { diffusion-evapo- } \\
\text { ration and Spray } \\
\text { drying }\end{array}$ & Sodium oleate & $\begin{array}{l}\text { Particle size: } \\
11.4-17 \mu \mathrm{m} \\
\text { MMAD: } 6.7-9.1 \mu \mathrm{m} \\
\text { EE: } 89-90 \%\end{array}$ & $\begin{array}{l}\text { Schoubben et al. } \\
\text { (2010) }\end{array}$ \\
\hline
\end{tabular}


Table 1 (continued)

\begin{tabular}{|c|c|c|c|c|c|c|}
\hline Particles & Drug & Indication & $\begin{array}{l}\text { Preparation Tech- } \\
\text { nique }\end{array}$ & Excipients & $\begin{array}{l}\text { Particle properties } \\
\text { and outcome }\end{array}$ & References \\
\hline $\begin{array}{l}\text { Large porous PLGA } \\
\text { MPs }\end{array}$ & $\begin{array}{l}\text { Doxorubicin and p53 } \\
\text { gene }\end{array}$ & Lung cancer & $\begin{array}{l}\text { Double emulsion- } \\
\text { solvent evaporation } \\
\text { (w/o/w) }\end{array}$ & $\begin{array}{l}\text { Ammonium bicar- } \\
\text { bonate }\end{array}$ & $\begin{array}{l}\text { Particle size: } \\
21.1-26.6 \mu \mathrm{m} \\
\text { EE: } 88.2 \% \text { (doxo- } \\
\text { rubicin), } 36.5 \% \\
\text { (plasmid) } \\
\text { Enhanced in vitro } \\
\text { anti-tumor and } \\
\text { apoptosis }\end{array}$ & Shi et al. (2014) \\
\hline PLGA MPs & PGE1 & $\begin{array}{l}\text { Pulmonary arterial } \\
\text { hypertension }\end{array}$ & $\begin{array}{l}\text { Double emulsion- } \\
\text { evaporation } \\
\text { (w/o/w) }\end{array}$ & HP $\beta C D, P V A$ & $\begin{array}{l}\text { Particle size: } \\
\text { 8.5-14.5 } \mu \mathrm{m} \\
\text { MMAD: } 0.7-5.5 \mu \mathrm{m} \\
\text { Tapped density: } \\
0.1-0.4 \mathrm{~g} / \mathrm{cm}^{3} \\
\text { PDI: } 0.1-1.7 \\
\text { FPF: } 35-92 \% \\
\text { Bioavailability: } \\
\text { 67-91\% }\end{array}$ & Gupta et al. (2011) \\
\hline PLGA MPs & Rifapentine & Tuberculosis & $\begin{array}{l}\text { Single emulsion- } \\
\text { evaporation }(\mathrm{o} / \mathrm{w}) \\
\text { and spray drying }\end{array}$ & PVA & $\begin{array}{l}\text { MMAD: } 2.4-3.0 \mu \mathrm{m} \\
\text { Span 2 } \\
\text { FPF: } 52-57 \% \\
\text { ED: } 81-86 \%\end{array}$ & $\begin{array}{l}\text { Parumasivam et al. } \\
\text { (2016) }\end{array}$ \\
\hline $\begin{array}{l}\text { Large porous PLGA } \\
\text { MPs }\end{array}$ & Cinaciguat & $\begin{array}{l}\text { Pulmonary hyperten- } \\
\text { sion }\end{array}$ & $\begin{array}{l}\text { Single emulsion- } \\
\text { evaporation }(\mathrm{o} / \mathrm{w})\end{array}$ & $\begin{array}{l}\text { PVA, PVP, Pluronic } \\
\text { F127 }\end{array}$ & $\begin{array}{l}\text { MMAD: } 4.8-6.2 \mu \mathrm{m} \\
\text { FPF: } 19.8-36 \% \\
\text { Retention }>36 \mathrm{~h} \\
\text { Sustained drug } \\
\text { release }\end{array}$ & Ni et al. (2017) \\
\hline PLGA MPs & Levofloxacin & Cystic fibrosis & $\begin{array}{l}\text { Double emulsion- } \\
\text { evaporation } \\
\text { (w/o/w) with a } \\
\text { membrane homog- } \\
\text { enization }\end{array}$ & Lauric acid, PVA & $\begin{array}{l}\text { ED: } 85.0 \% \\
\text { FPF: } 30.2 \% \\
\text { MMAD: } 7.1 \mu \mathrm{m} \\
\text { Sustained-release: } \\
75 \% \text { in } 72 \mathrm{~h}\end{array}$ & Gaspar et al. (2019) \\
\hline $\begin{array}{l}\text { Large porous PLGA } \\
\text { MPs }\end{array}$ & Curcumin & Cystic fibrosis & $\begin{array}{l}\text { Double emulsion- } \\
\text { evaporation } \\
\text { (w/o/w) }\end{array}$ & PVA & $\begin{array}{l}\text { Particle size }>10 \mu \mathrm{m} \\
\text { MMAD: } 3.12 \mu \mathrm{m} \\
\text { FPF: } 13.41 \% \\
71 \% \text { release in } 9 \mathrm{~h}\end{array}$ & Hu et al. (2018) \\
\hline
\end{tabular}

$M M A D$ mass median aerodynamic diameter, $E D$ emitted dose $\%, F P F$ fine particle fraction $\%, E E$ encapsulation efficiency $\%, P D I$ polydispersity Index, $P V P$ polyvinyl pyrrolidone, $P V A$ polyvinyl alcohol, $H P \beta C D$ hydroxypropyl- $\beta$-cyclodextrin, $P E M A$ poly(ethylene-alt-maleic anhydride), TRAIL tumor necrosis factor-related apoptosis inducing ligand; PGE1, prostaglandin E1, PEI polyethyleneimine; PEC polyethylene carbonate, $P E G$ polyethylene glycol

good porosity of the MPs is a desired feature for inhalation (Ungaro et al. 2006).

Large porous MPs (LPMs) demonstrate a sophisticated formulation to improve deep lung localization and avoid macrophage clearance (Fig. 1). They are light particles with ideal characteristics for pulmonary delivery, including large geometric diameter $(5-30 \mu \mathrm{m})$, low density $\left(<0.4 \mathrm{~g} / \mathrm{cm}^{3}\right)$, and acceptable aerodynamic diameter $(1-3 \mu \mathrm{m})$ (Edwards et al. 1998). The numerous pores in LPMs make them light enough to ensure their deep lung deposition through inhalation. However, MPs with geometric diameters $<5 \mu \mathrm{m}$ are susceptible to aggregation through van der Waals force. This causes some of the drugs to be retained in the device, resulting in a lower yield of drug delivery to the lungs. In addition, 1-3 $\mu \mathrm{m}$ particles are phagocytosed by macrophage clearance in the lung, thus, decreasing their activity (Patton and Byron 2007; Ungaro et al. 2012). Alveolar macrophages cannot capture large MPs with geometric diameters $\geq 20 \mu \mathrm{m}$; hence, there is a prolonged residence time in the lung. This implies that light particles as well as large ones $(5-30 \mu \mathrm{m})$ are highly desirable for drug delivery into deep lungs. Different types of porogens have potentials for the preparation of LPMs including extractable porogens (pluronics), effervescent porogens (ammonium bicarbonate), osmogens (cyclodextrins), and gas bubbles (hydrogen peroxide/ catalase) (Abdelaziz et al. 2018). Extractable porogens and osmogens manifest the drawback of drug leakage through pores because of aqueous channels formed within polymeric microspheres. Effervescent porogens are preferred to minimize drug loss and improve the encapsulation efficiency. Kim et al. prepared doxorubicin-encapsulated large porous PLGA MPs (DOX-LPM) by a water-in-oil-in-water (w/o/w) double emulsion-evaporation technique using ammonium bicarbonate as a gas-foaming porogen (Kim et al. 2012). 


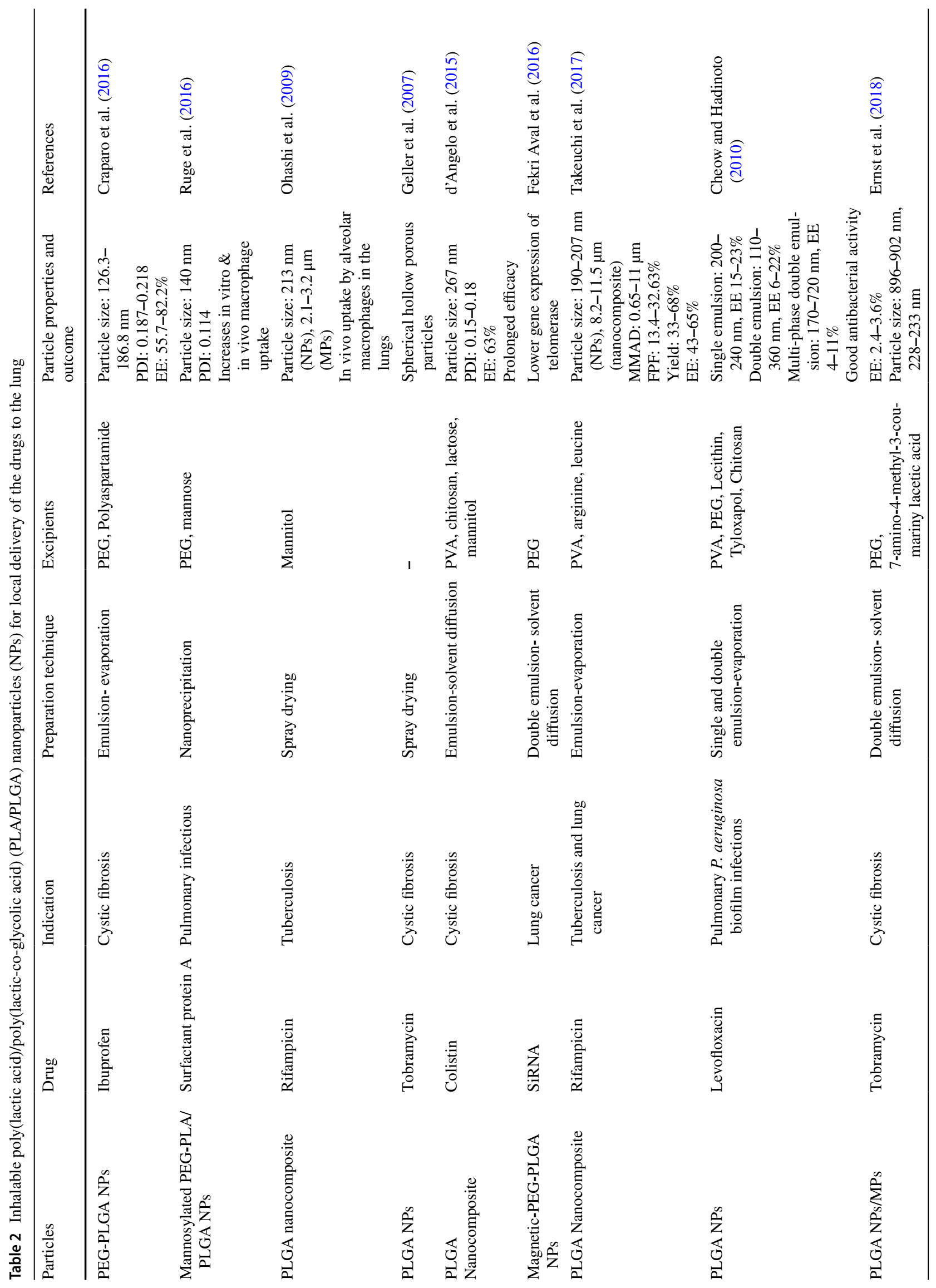




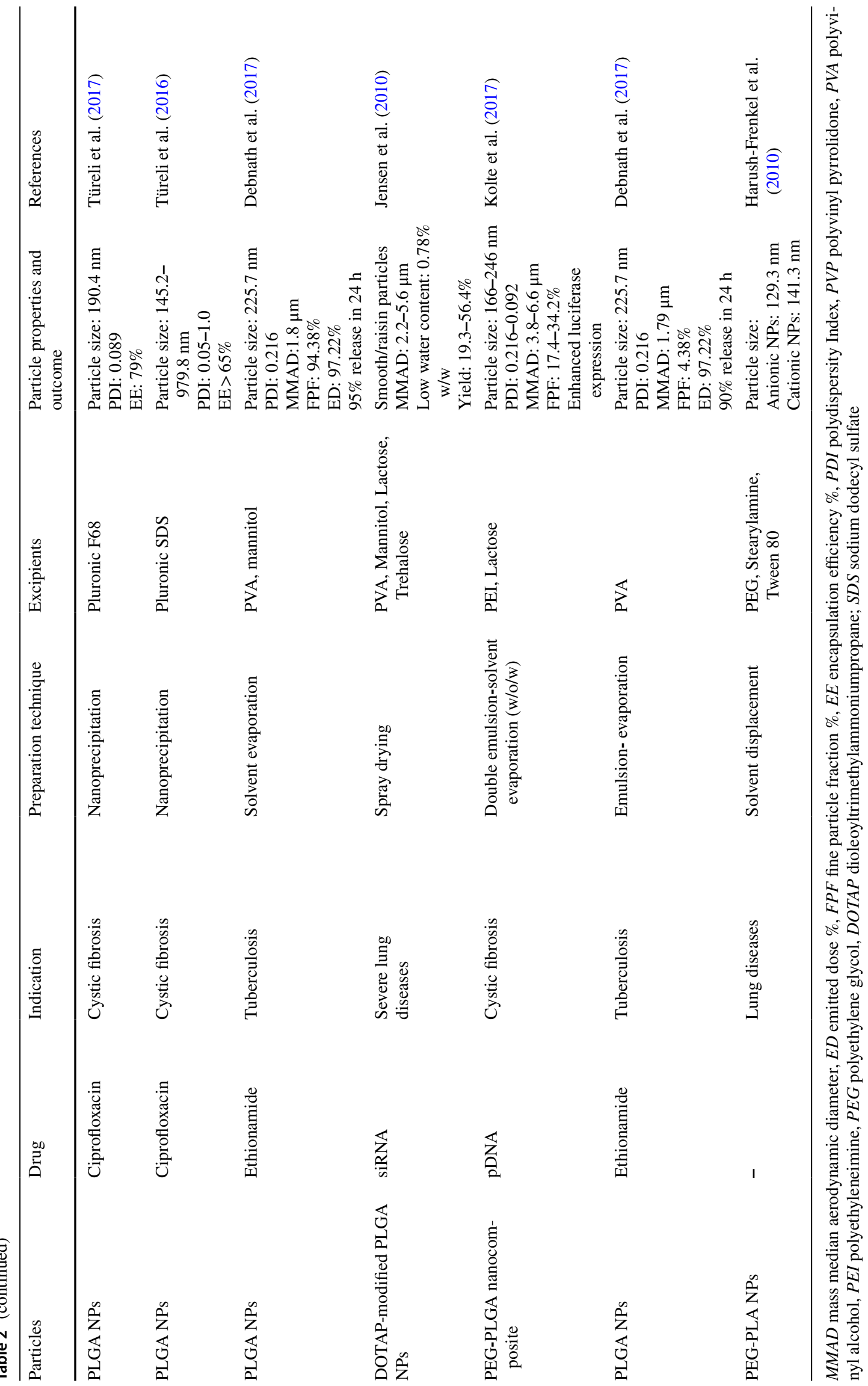


Table 3 Inhalable poly(lactic acid)/poly(lactic-co-glycolic acid) (PLA/PLGA) particles for peptides, proteins, genes, or other systemic drug delivery systems

\begin{tabular}{|c|c|c|c|c|c|c|}
\hline Particles & Drug & Indication & $\begin{array}{l}\text { Preparation tech- } \\
\text { nique }\end{array}$ & Excipients & $\begin{array}{l}\text { Particle properties } \\
\text { and outcome }\end{array}$ & References \\
\hline $\begin{array}{l}\text { PLGA } \\
\text { MPs }\end{array}$ & Rosiglitazone & $\begin{array}{l}\text { Diabetes and pul- } \\
\text { monary arterial } \\
\text { hypertension }\end{array}$ & $\begin{array}{l}\text { Double emulsion- } \\
\text { evaporation } \\
(\mathrm{w} / \mathrm{o} / \mathrm{w})\end{array}$ & PVA, PEI & $\begin{array}{l}\text { MMAD: } 6.92 \mu \mathrm{m} \\
\text { Release: } 87.9 \% \text { in } \\
24 \mathrm{~h}\end{array}$ & Rashid et al. (2018) \\
\hline $\begin{array}{l}\text { Large porous } \\
\text { PLGA MPs }\end{array}$ & Insulin & Diabetes & $\begin{array}{l}\text { Double emulsion- } \\
\text { evaporation }\end{array}$ & $\begin{array}{l}\text { HP } \beta C D \text {, phenol- } \\
\text { phthalein, Tween } \\
\text { 80, PVA }\end{array}$ & $\begin{array}{l}\text { Particle size: } \\
25.1-31.4 \mu \mathrm{m} \\
\text { MMAD: } 10-19 \mu \mathrm{m} \\
\text { EE: Insulin } \rightarrow 52- \\
100 \% \\
\text { EE: HP } \beta C D \rightarrow 24- \\
60 \%\end{array}$ & Ungaro et al. (2006) \\
\hline $\begin{array}{l}\text { Albumin-coated } \\
\text { porous hollow } \\
\text { PLGA MPs }\end{array}$ & $\begin{array}{l}\text { Palmityl- } \\
\text { acylated } \\
\text { exendin-4 }\end{array}$ & Diabetes & $\begin{array}{l}\text { Double emulsion- } \\
\text { evaporation } \\
(\mathrm{w} / \mathrm{o} / \mathrm{w})\end{array}$ & $\begin{array}{l}\text { PEMA, HP } \beta C D, \\
\mathrm{NaCl}\end{array}$ & $\begin{array}{l}\text { Particle size: } \\
17.2 \mu \mathrm{m} \\
\text { MMAD: } 3.2 \mu \mathrm{m}\end{array}$ & Kim et al. (2011) \\
\hline PLGA MPs & BSA & Vaccine delivery & $\begin{array}{l}\text { Supercritical } \\
\mathrm{CO}_{2} \text {-spray drying }\end{array}$ & L-leucine & $\begin{array}{l}\text { Particle size: } \\
\text { 9.6-10.6 } \mu \mathrm{m} \\
\text { MMAD: } 1.7- \\
3.5 \mu \mathrm{m} \\
\text { FPF: } 25.4-43.4 \% \\
\text { ED: } 95.3-99.6 \%\end{array}$ & Tavares et al. (2017) \\
\hline PEG-PLGA NPs & $\begin{array}{l}\text { DNA, Protein } \\
\text { EPO }\end{array}$ & - & $\begin{array}{l}\text { Emulsion-solvent } \\
\text { evaporation }\end{array}$ & PVA, PEG & $\begin{array}{l}\text { Particle size: } \\
160-191 \mathrm{~nm} \\
\text { PDI:0.07-0.14 } \\
\text { Bi-phasic drug } \\
\text { release }\end{array}$ & Menon et al. (2014) \\
\hline Hallow PLGA MPs & DNA & - & $\begin{array}{l}\text { Double emulsion- } \\
\text { evaporation } \\
(\mathrm{w} / \mathrm{o} / \mathrm{w})\end{array}$ & Pluronic L92 & $\begin{array}{l}\text { Particle size: } \\
7.85 \mu \mathrm{m} \\
\text { Span: } 1.5 \\
\text { MMAD: } 3.8 \mu \mathrm{m} \\
\text { Density: } 0.24 \mathrm{~g} / \\
\mathrm{cm}^{3} \\
\text { EE: } 15-28 \%\end{array}$ & $\begin{array}{r}\text { Mohamed and van } \\
\text { der Walle (2006) }\end{array}$ \\
\hline $\begin{array}{l}\text { PLGA-chitosan } \\
\text { MPs/NPs }\end{array}$ & Calcitonin & Osteoporosis & $\begin{array}{l}\text { Emulsion-solvent } \\
\text { diffusion }\end{array}$ & $\begin{array}{l}\text { Span 80, PVA, } \\
\text { Chitosan }\end{array}$ & $\begin{array}{l}\text { Particle size: } \\
660 \mathrm{~nm} \text { (NPs), } \\
7.07 \mu \mathrm{m} \text { (MPs) }\end{array}$ & $\begin{array}{l}\text { Yamamoto et al. } \\
\text { (2005) }\end{array}$ \\
\hline
\end{tabular}

$M M A D$ mass median aerodynamic diameter, $E D$ emitted dose $\%$; fine particle fraction $\%, E E$ encapsulation efficiency $\%, P D I$ polydispersity Index, $P V P$ polyvinyl pyrrolidone, $P V A$ polyvinyl alcohol, $H P \beta C D$ hydroxypropyl- $\beta$-cyclodextrin, $P E I$ polyethyleneimine, $P E G$ polyethylene glycol, $S D S$ sodium dodecyl sulfate, $P E M A$ poly(ethylene-alt-maleic anhydride), $B S A$ bovine serum albumin, $E P O$ erythropoietin

The DOX-LPM with a geometric diameter of $14 \mu \mathrm{m}$ and aerodynamic diameter of $3.6 \mu \mathrm{m}$ showed successful aerodynamic behavior-they were deposited in the lungs and remained for up to 2 weeks. In a mouse model of B16F10 melanoma metastasis, there was a significant anti-tumor effect in the DOX-LPM-treated group when compared with the untreated group.

Nishimura et al. constructed porous and non-porous PLGA MPs for inhalation by using a single-step emulsionevaporation method (Nishimura et al. 2017). They prepared porous particles having a geometric diameter of 5-10 $\mu \mathrm{m}$ with very low tapped density $\left(0.04 \mathrm{~g} / \mathrm{cm}^{3}\right)$. The particles with a geometric diameter of $5 \mu \mathrm{m}$ showed lower emitted dose and higher fine particle fraction (FPF) than those with a geometric diameter of $10 \mu \mathrm{m}$. PLGA MPs that were prepared in the presence of Tween 85 were non-porous, and they had the highest emitted dose with the lowest FPF, indicating a weak aerosol performance. From this observation, it was suggested that an electrostatic attraction force between the porous particles and the capsules decreased the emitting efficiency of the MPs from the capsules. Their study showed that the aerodynamic diameter of the porous PLGA particles was approximately $5 \mu \mathrm{m}$ with an approximate FPF value of $40-65 \%$; however, the aerodynamic diameter of the nonporous particles was approximately $14 \mu \mathrm{m}$ with a lower FPF $(<20 \%)$. These results indicate that the porous particles had unique internal structures and proper aerodynamic properties attributable to the spontaneous emulsion preparation. Therefore, porous PLGA MPs can provide a suitable aerodynamic diameter for inhalation and deposition in the lungs 
Fig. 1 Different types of polymeric poly(lactic acid)/ poly(lactic-co-glycolic acid) (PLA/PLGA) particles as carriers for pulmonary drug delivery

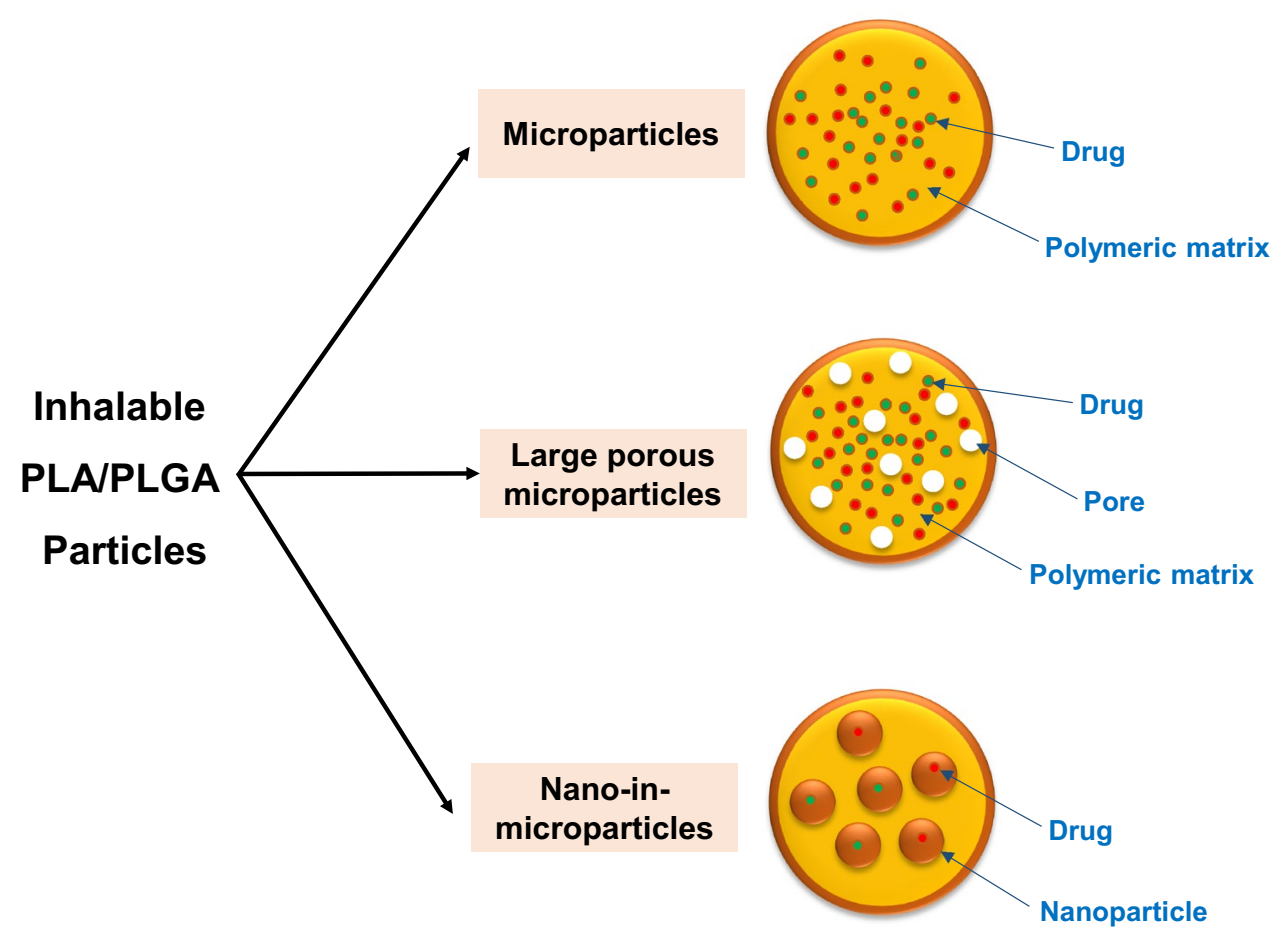

to achieve high and efficient delivery of therapeutic agents to the lung.

\section{Nano-in-microparticles (Nanocomposites)}

NPs as polymeric carriers for respiratory delivery have the ability to enter the intracellular compartments and evade the alveolar macrophages and mucociliary clearance mechanisms, resulting in enhanced bioavailability and prolonged drug residence time (Rogueda and Traini 2007). Moreover, NPs can be modified for drug targeting to a specific lung tissue and cell populations (Hillaireau and Couvreur 2009). The interaction of NPs with lung tissue often depends on the size and surface charge of the particles. Hence, adequate engineering of particles at the nanosize level to produce NPs with different features (size, morphology, and zeta-potential) is an important aspect with excipient selection and formulation design (Lai et al. 2009).

However, the pulmonary delivery of NPs has two major drawbacks: NPs, with the exception of particles $<50 \mathrm{~nm}$, are generally exhaled upon inhalation, and they are prone to aggregation owing to their high surface energy (Rogueda and Traini 2007; Yang et al. 2008). To overcome these drawbacks, the most widely employed inhalation approach is the nebulization of aqueous dispersions of NPs. However, this approach can generate problems with instability of the nanosuspensions, such as aggregation and/or drug leakage (Dailey et al. 2003). These problems can be overcome by applying NPs as dry powder. Direct drying of NPs suspensions has been shown to have some success in generating dry powders composed of agglomerated
PLGA NPs, but with this approach, it may be difficult to preserve the integrity of NPs, including in terms of inappropriate overflow and aerosolization properties (Ungaro et al. 2012). As an alternative approach, particles obtained by the embedding of drug-loaded PLGA NPs within sugar MPs have been suggested to improve the formulation stability and aerodynamic properties of the entrapped NPs (Al-Qadi et al. 2012; Sham et al. 2004). The NPs-incorporated MPs, also termed nano-inmicroparticles, are designed to release primary NPs from inert microcarriers into lung lining fluid after reaching the alveolar surface (Abdelaziz et al. 2018; Ungaro et al. 2012).

\section{Preparation of inhalable PLA/PLGA particles}

Several studies have investigated the various preparation methods for polymeric MPs/NPs and their applications for pulmonary DDS (Bailey and Berkland 2009; Menon et al. 2014; Mundargi et al. 2008). The conventional methods used in the production of NPs and MPs involve single/double emulsion-solvent evaporation, spray freeze drying, spray drying, supercritical fluid drying, and coacervation (Fig. 2). Each process has its advantages as well as limitations (Campardelli et al. 2016; Emami et al. 2018a).

\section{Single/double emulsion-solvent evaporation technique}

Emulsion-solvent evaporation method has been extensively applied to prepare biodegradable polymeric carriers for 
respiratory drug delivery (Patil and Sarasija 2012). This technique involves the preparation of oil/water emulsion and subsequent removal of the organic phase through evaporation procedure. The oil phase diffuses out of the polymer matrix into the water phase and finally is evaporated, producing drug-encapsulated polymeric MPs/NPs (Patil and Sarasija 2012). One of the easiest procedures used in the preparation of MPs and NPs is the single emulsion-solvent evaporation method. Hydrophobic drugs are dissolved with polymer in an organic phase, which are then emulsified in an aqueous phase. Different types of emulsions, such as oil in water $(\mathrm{o} / \mathrm{w})$, oil in oil (o/o), or water in oil (w/o), were prepared by exposure to a high shearing energy, including homogenizing, ultrasonication, or milling. The organic phase is evaporated under vacuum or low pressure by the extraction method. The tailored particle is then lyophilized for long-term storage (Lee et al. 2016).

For hydrophilic drugs, the double w/o/w emulsion-solvent evaporation process has been widely employed. However, this technique often results in low drug loading owing to the difficulty in controlling the migration of hydrophilic drugs from the inner to the outer aqueous phase. Some formulation approaches have been applied to enhance the incorporation efficiency of hydrophilic drugs including the adjustment of aqueous phase $\mathrm{pH}$, ion-pairing using counter ions to drug molecule, and addition of fatty acid to organic phase (Govender et al. 1999; Holmkvist et al. 2016). For the preparation of PLGA MPs of a water-soluble drug-levofloxacin, Gaspar et al. added fatty acid (lauric acid) to the oil phase or the saturated aqueous phase with levofloxacin to avoid the escape of the drug from the organic phase in the $\mathrm{w} / \mathrm{o} / \mathrm{w}$ emulsion, resulting in a higher drug encapsulation when compared with the conventional double emulsion method (Gaspar et al. 2019). Although the addition of lauric acid resulted in a larger particle size and no sustained release, the saturation of the aqueous phase with levofloxacin resulted in an appropriate particle size for inhalation $(\sim 5 \mu \mathrm{m})$ and a controlled drug release.

\section{Spray drying}

Spray drying (SD) is the commonly used particle engineering method for the preparation of particles with appropriate size and morphology for pulmonary delivery (Muttil et al. 2007; Nandiyanto and Okuyama 2011). The SD method includes three phases comprising of atomization,

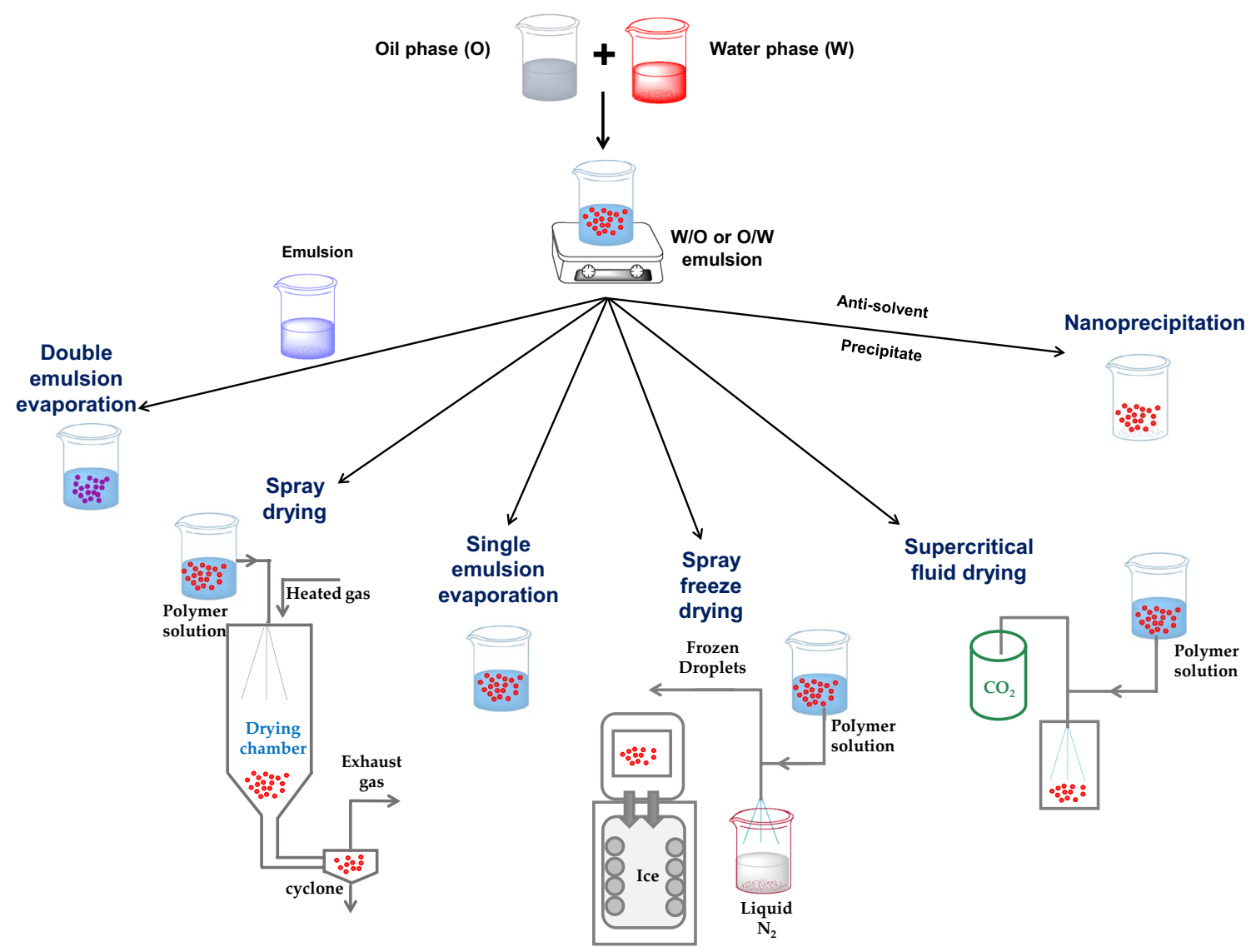

Fig. 2 Preparation techniques of poly(lactic acid)/poly(lactic-co-glycolic acid) (PLA/PLGA) particles for pulmonary drug delivery 
drying in the hot chamber, and separation of particles. The feeding solution is atomized through nozzles into a drying chamber. The generation of polymeric droplet and subsequent dehydration are performed in a chamber with hot air flow. The dried powders are transferred into a cyclone (Faghihi et al. 2014; Nandiyanto and Okuyama 2011; Ramezani et al. 2013). Yamamoto et al. prepared insulinloaded PLGA nanocomposite particles for inhalation by the spray-fluidized bed granulation method (Yamamoto et al. 2007). At first, PLGA NPs were prepared, insulin was encapsulated, and finally nanocomposites were prepared. Briefly, PLGA and 6-coumarin were dissolved in an organic solvent mixture, and the resulting solution was injected into polyvinylalcohol solution. The evaporation of the organic solvent resulted in NPs with an average size of $250 \mathrm{~nm}$. Next, lyophilized powder and mannitol were suspended in the aqueous phase and spray-dried in a fluidized bed granulation system. In this method, the feeding solution was sprayed into the hot chamber, and the spray-dried particles are dispersed into the granulation zone by a rinsing pulsed air jet. Finally, NPs were granulated by the coalescence of wet particle collision, which resulted in the formation of nanocomposites. The average aerodynamic diameter of the tailored particles was reported to be $1-10 \mu \mathrm{m}$, as measured by cascade impaction. The nanocomposites exhibited greater aerodynamic performance than that by freeze-dried NPs. The nanocomposite granules demonstrated preferable physicochemical characteristics for inhalation and lung dispersion in both in vitro and in vivo studies.

\section{Spray freeze drying}

Spray freeze drying (SFD) method combines the advantages of both SD and freeze-drying techniques (Abdelaziz et al. 2018). Furthermore, this method can overcome the limitations of SD method for heat sensitive molecules. In SFD process, a feeding solution is atomized through a nozzle into a vapor above liquid nitrogen, frozen in liquid nitrogen, and subsequently lyophilized in a freeze dryer (Emami et al. 2018a, b). Ali and Lamprecht studied the SFD procedures used for the synthesis of inhalable nanocomposite microcarriers suitable for pulmonary deposition (Ali and Lamprecht 2014). In this study, spray freeze-dried MPs with an aerodynamic diameter of $3.0 \pm 0.5 \mu \mathrm{m}$ were prepared, and they had larger specific surface areas $\left(67-77 \mathrm{~m}^{2} / \mathrm{g}\right)$ and lower densities $\left(0.02 \mathrm{~g} / \mathrm{cm}^{3}\right)$ than those of the MPs similarly prepared by SD method. The SFD showed better performance than SD in terms of maintaining the particle size of NPs following reconstitution. Furthermore, SFD provided highly porous MPs with proper aerodynamic diameters for inhalation.

\section{Supercritical fluid drying}

A particle generation process using supercritical fluids (SCF) has been proposed for the preparation of polymeric particles by dehydration in the absence of extreme temperature (Campardelli et al. 2012; Tavares et al. 2017). SCF drying (SCFD) uses materials such as carbon dioxide or methanol above its critical pressure and temperature. The critical temperature of a liquid is the temperature at which its vapor cannot be liquefied. The pressure that is required to condense a gas at its critical temperature defines its critical pressure. SCF above its critical point exhibits the appropriate characteristics of gas and liquid, including the flow characteristics of a gas (low viscosity) and the solubility of a solute. SCF has the potential to penetrate within materials because they do not exhibit any surface tension, and the solvent power is proportional to their density. SCFD is a tunable procedure that can control the density of SCF and the solubility of a solute by altering the pressure or temperature used during the process (Emami et al. 2018b). Carbon dioxide is the most frequently used SCF because it is nontoxic, inexpensive, and nonflammable. It also has a low critical point $\left(31.1^{\circ} \mathrm{C}\right.$ and 73.8 bar), which makes it suitable for thermo-sensitive drugs at minimal procedure cost (Tavares et al. 2017).

Tavares et al. constructed dry powder PLGA MPs by supercritical carbon dioxide-assisted SD (SCF-SD) for vaccine delivery to the lung (Tavares et al. 2017). Vaccine formulations were prepared using bovine serum albumin (BSA) as a model vaccine in the presence of L-leucine. The aerodynamic performance of dry powder inhaler was characterized using the Andersen cascade impactor. Tailored BSAPLGA particles showed fine particle fraction of $43.4 \%$ with an aerodynamic diameter of $1.7-3.5 \mu \mathrm{m}$, which represents the proper characteristics for inhalation. The authors concluded that the addition of L-leucine in BSA formulation as a dispersibility enhancer could overcome the stress in SCF-SD method. In addition, they demonstrated that the SCF-SD process is appropriate for the preparation of PLGA dry powder inhaler.

\section{Nanoprecipitation}

Nanoprecipitation involves crystallization and precipitation using anti-solvent jets. Crystalline drug particles with proper size distribution are produced by controlled crystallization. Inhalable NPs can be prepared by rapid precipitation using anti-solvents. In addition, ultrasonic radiation has been applied to control precipitation. Various drugs against asthma were prepared using the sonocrystallization technique (Patil and Sarasija 2012). Recently, Türeli et al. constructed ciprofloxacin-loaded PLGA NPs against Pseudomonas aeruginosa infections in cystic fibrosis (Türeli et al. 2017). PLGA NPs were prepared by an optimized 
nanoprecipitation method using Microjet Reactor. The tailored particles had a particle size of $190.4 \pm 28.6 \mathrm{~nm}$ with polydispersity index of 0.089 and encapsulation efficiency of approximately $79 \%$. Compared with the native drug, ciprofloxacin-loaded PLGA NPs showed greater anti-microbial activity and reduced mucus turbidity in an in vitro assay. Additionally, the NPs demonstrated acceptable stability in the mucus. The authors concluded that ciprofloxacin-loaded biodegradable PLGA NPs efficiently offer promising treatment strategies for chronic pulmonary infections (Türeli et al. 2017).

\section{Applications of PLA/PLGA particles to pulmonary drug delivery}

\section{Local drug delivery}

An effective local drug delivery is the obvious choice for treating lung diseases such as tuberculosis, COPD, cystic fibrosis, asthma, and lung cancer (Pison et al. 2006). Tables 1 and 2 summarize the PLA/PLGA MPs and NPs studied for local drug delivery against various respiratory diseases. For respiratory diseases, drug delivery with a novel targeting agent to the lung is required for adequate drug concentrations at the pathology site, with minimal systemic absorption and undesired side effects. An ideal inhaler should provide sustained effects, retain drugs within the lung, reduce the prescription frequency, and enhance patients' compliance with the therapeutic regimen (Yang et al. 2009). Polymeric MPs/NPs retained in the lungs have the potential to provide high drug concentration and prolonged drug residence time in the lung with minimum drug exposure to the blood circulation (Harush-Frenkel et al. 2010). Lu et al. encapsulated recombinant Mycobacterium tuberculosis antigen 85B (Ag85B) by SD method into PLGA MPs for the treatment of tuberculosis (Lu et al. 2007). PLGA MPs of 3-4 $\mu \mathrm{m}$ were suitable for targeting macrophages and for aerosol delivery to the lung. PLGA-rAg85B MPs were able to stimulate an antigen response that was twofold higher than that by the pure rAG85B.

\section{Systemic drug delivery}

Respiratory drug delivery provides a non-invasive route of drug administration targeting the systemic blood circulation, as the lungs have a large alveolar surface area, rich blood vascularity, and thin epithelial barrier (Rytting et al. 2008; Sung et al. 2007). Moreover, first-pass metabolism effect can be minimized by pulmonary delivery, which can be a good alternative delivery system for therapeutic peptides and proteins (Rytting et al. 2008). The pulmonary delivery of therapeutic proteins and peptides, such as calcitonin (Poursina et al. 2016), trastuzumab (Ramezani et al. 2014), and insulin (Exubera ${ }^{\circledR}$ and Afrezza ${ }^{\circledR}$ ) (Al-Tabakha 2015), have been investigated for the treatment of osteoporosis, breast cancer, and diabetes, respectively (Table 3 ). For systemic delivery through the pulmonary route, some specific physical barriers, such as blood proteolytic degradation, renal clearance, and hepatic first-pass metabolism, should be considered, and an effective dosage form of the drug is highly required to be absorbed through the alveolar and bronchial epithelium (Depreter et al. 2013). The low permeability of the membrane to macromolecules is one of the restricting factors in crossing the alveolar capillary membrane. The absorption of peptides and proteins through the double-layered phospholipid membrane by diffusion is restricted owing to their large size and hydrophilic nature. The absorption kinetics of therapeutic proteins into the systemic blood circulation are usually inversely related to the molecular weight, with lower molecular weights resulting in a lower "time of maximum concentration" $\left(\mathrm{T}_{\max }\right)$ and higher "maximum plasma concentration" $\left(\mathrm{C}_{\max }\right)$ (Hu et al. 2016). Some approaches can enhance the adsorption of peptides and proteins through the capillary membrane in the lungs. Absorption enhancers, including bile salts, surfactants, chitosan, citric acid, cyclodextrins, and lipid-based particles (liposomes and solid lipid NPs), are recommended to overcome the low absorption (Emami et al. 2018b). The polymeric carriers can also protect the drug from physicochemical and enzymatic degradations (Campardelli et al. 2016).

\section{Vaccine delivery}

There have been many studies of PLGA particles application for the delivery of vaccines to induce efficient immunity in various diseases such as hepatitis B, tuberculosis, chlamydia, leishmaniasis, toxoplasmosis, and malaria (Allahyari and Mohit 2016). The PLGA particles could achieve a long-lasting effect in different disease models; hence, the need for multiple injections associated with conventional vaccines can be avoided (Dewangan et al. 2018; Saini et al. 2011). In a study by Feng et al., a single subcutaneous injection of PLGA MPs loaded with recombinant hepatitis B surface antigen ( $\mathrm{HBsAg}$ ) in mice resulted in antibody responses comparable to those of three injections of the conventional HBsAg vaccine (Feng et al. 2006). MPs have been used frequently to improve vaccine delivery, in which PLGA MPs with diameters 1-10 $\mu \mathrm{m}$ are capable of interacting with antigen presenting cells to induce cell-mediated immunity (Audran et al. 2003; Vordermeier et al. 1995). Antigen-loaded PLA or PLGA particles could enter the phagosome/phagolysosome and transport some antigens to the cytoplasm (Men et al. 1999). Furthermore, polymeric MPs could induce immune responses and mucosal immunization (O'Hagan et al. 1998). Antigens loaded in MPs could 
more efficiently present antigen to macrophages by 100 - to 1000 -fold and offer superior immunization in comparison with the soluble antigen (Lu et al. 2007).

\section{Protein and peptide delivery}

The therapeutic use of biomolecules has been substantially increased by the development of biotechnology techniques, and various peptides and proteins have been shown to have therapeutic potential against various diseases. However, these biomolecules have therapeutic limitations owing to chemical and physical instability, high susceptibility to proteolytic degradation, and short circulation half-life requiring multiple injections (Mundargi et al. 2008; Song et al. 2017). Several strategies for sustained parenteral form and alternative administration route of drugs have been suggested as solutions to the therapeutic limitations of biomolecules (Shire et al. 2004; Tyler et al. 2016). Although the inhaled application of encapsulated proteins and peptides into PLA/ PLGA particles seems to be a method of choice, some preconditions should be considered to ensure the administration of sufficient and reproducible drug doses for the treatment of systemic diseases. It is difficult to achieve efficient bioavailability with the pulmonary delivery of macromolecules because of local toxicity, immunogenicity, large size of macromolecules, humidity, mucociliary clearance, presence of hydrolytic enzymes, and macrophage clearance (Agrahari et al. 2016). Furthermore, the stability issue of peptides incorporated into PLGA MPs needs to be considered because several peptide drugs such as calcitonin, octreotide, goserelin, and leuprolide are acylated by their interaction with PLGA structures (Ahn et al. 2011; Guo et al. 2019; Na and DeLuca 2005; Na et al. 2003, 2007; Park et al. 2007; Shirangi et al. 2016).

\section{Gene delivery}

Polymeric particles are favorable in the drug delivery of nucleic acids to the lung owing to the localized effect and the reduced systemic side effects (Jensen et al. 2010; Menon et al. 2014). The traditional delivery of DNA are restricted by enzymatic degradation, limited bioavailability, and physicochemical instability, but the polymeric system can overcome these limitations because of the large alveolar surface area for rapid cellular uptake, prolonged retention of the drug, and lower effective dose providing lower toxicity risk compared with systemic delivery (Menon et al. 2014). Jensen et al. studied SD of siRNA-loaded PLGA NPs into nanocomposite MPs for pulmonary DDS (Jensen et al. 2010). The siRNA-loaded NPs were prepared by the double emulsion-evaporation technique, and the nanocomposite was then synthesized using SD of PLGA NPs suspension in the presence of various carbohydrates (mannitol, trehalose, and lactose). The optimum formulation of siRNA-loaded nanocomposite prepared in the presence of mannitol resulted in a product with low moisture content $(0.78 \% \mathrm{w} / \mathrm{w})$ and a good aerodynamic diameter for inhalation. The in vitro results showed that there was no significant difference between the biological activity of the siRNA extracted from siRNAPLGA nanocomposite and that from unmodified siRNA. Similarly, siRNA-PLGA NPs mixed with lipofectamine 2000 downregulated $(68 \%)$ the enhanced green fluorescent protein expression in H1299 non-small lung cancer cells, indicating that the biological activity of the siRNA was conserved with the SD method.

Kolte et al. reported composite NPs of the PLGA and polyethyleneimine (PEI) as an alternative to viral and liposomal vectors for the pulmonary delivery of pDNA (Kolte et al. 2017). NPs with different weight ratios of PLGA/PEI were prepared by double (w/o/w) emulsion solvent evaporation method. The encapsulation efficiency of pDNA was increased by the addition of PEI. The in vitro cell uptake and transfection studies revealed that NPs with $10 \% \mathrm{w} / \mathrm{w}$ PEI were more efficient, but they exhibited significant cytotoxicity. PEGylation of these composite NPs reduced their toxicity and enhanced the cellular uptake and pDNA expression. PEGylation also improved the diffusion of NPs through the mucus barrier and inhibited the uptake of NPs by macrophages of the lung. Finally, PEGylated composite NPs were freeze-dried with lactose carrier particles, resulting in improved aerosolization properties and lung deposition, without influencing the bioactivity of pDNA.

\section{Conclusions}

The numbers of polymeric particulate systems for pulmonary therapeutic applications have increased with the widespread use of biocompatible polymers. PLA and PLGA are attractive biopolymers useful for inhalable particle formulations owing to their biocompatibility and biodegradability. MPs and NPs obtained by different manufacturing techniques with PLA or PLGA have demonstrated significant potential as carriers for various local or systemic respiratory applications. The manufacturing techniques of PLA/PLGA MPs and NPs involve single/double emulsion-solvent evaporation method, spray drying, spray freeze drying, supercritical fluid drying, and nanoprecipitation. Adequately designed and engineered MPs and NPs can contribute to desirable pulmonary drug delivery characterized by sustained drug release to the lungs, prolonged drug action, reduction in therapeutic dose, low adverse effects, and improved patient compliance.

In the development of inhalable DDS, significant progress has been made by using liposomes with Alveofact ${ }^{\circledR}$ approved 
by FDA in 1990 for the treatment of acute respiratory distress syndrome and Arikace ${ }^{\circledR}$ (drug: amikacin) approved by FDA in 2018 for the treatment of Mycobacterium avium complex lung disease (Paranjpe and Muller-Goymann 2014; Shirley 2019). However, liposomes are prone to instability problem with the possibility of drug leakage during storage. Compared with liposome, polymeric MPs and NPs present higher structural integrity providing enhanced stability, higher drug loading, and prolonged drug release (Abdelaziz et al. 2018). Therefore, biodegradable PLA/PLGA-based MPs and NPs are highly beneficial carrier option for both local and systemic inhalation therapies.

Acknowledgements This work was supported by the National Research Foundation of Korea (NRF) grant funded by the Ministry of Science and ICT (NRF-2018R1A2B3004266)

\section{Compliance with ethical standards}

Conflict of interest The authors declare that they have no conflict of interest.

Statement of human and animal rights This article does not contain any studies with human and animal subjects performed by any of the authors.

Open Access This article is distributed under the terms of the Creative Commons Attribution 4.0 International License (http://creativecommons. org/licenses/by/4.0/), which permits use, duplication, adaptation, distribution and reproduction in any medium or format, as long as you give appropriate credit to the original author(s) and the source, provide a link to the Creative Commons license and indicate if changes were made.

\section{References}

Abdelaziz HM, Gaber M, Abd-Elwakil MM, Mabrouk MT, Elgohary MM et al (2018) Inhalable particulate drug delivery systems for lung cancer therapy: nanoparticles, microparticles, nanocomposites and nanoaggregates. J Control Release 269:374-392

Adi H, Young PM, Chan H-K, Agus H, Traini D (2010) Co-spray-dried mannitol-ciprofloxacin dry powder inhaler formulation for cystic fibrosis and chronic obstructive pulmonary disease. Eur J Pharm Sci 40:239-247

Agrahari V, Agrahari V, Mitra AK (2016) Nanocarrier fabrication and macromolecule drug delivery: challenges and opportunities. Ther Deliv 7:257-278

Ahn JH, Park EJ, Lee HS, Lee KC, Na DH (2011) Reversible blocking of amino groups of octreotide for the inhibition of formation of acylated peptide impurities in poly (lactide-co-glycolide) delivery systems. AAPS PharmSciTech 12:1220-1226

Alexis F (2005) Factors affecting the degradation and drug-release mechanism of poly (lactic acid) and poly [(lactic acid)-co(glycolic acid)]. Polym Int 54:36-46

Ali M (2010) Pulmonary drug delivery. In: Kulkarni VS (ed) Handbook of non-invasive drug delivery systems. Elsevier, Amsterdam, pp 209-246

Ali ME, Lamprecht A (2014) Spray freeze drying for dry powder inhalation of nanoparticles. Eur J Pharm Biopharm 87:510-517

Allahyari M, Mohit E (2016) Peptide/protein vaccine delivery system based on PLGA particles. Hum Vaccin Immunother 12:806-828
Al-Qadi S, Grenha A, Carrion-Recio D, Seijo B, Remunan-Lopez C (2012) Microencapsulated chitosan nanoparticles for pulmonary protein delivery: in vivo evaluation of insulin-loaded formulations. J Control Release 157:383-390

Al-Tabakha MM (2015) Future prospect of insulin inhalation for diabetic patients: the case of Afrezza versus Exubera. J Control Release 215:25-38

Amatya S, Park EJ, Park JH, Kim JS, Seol E et al (2013) Drug release testing methods of polymeric particulate drug formulations. $\mathrm{J}$ Pharm Investig 43:259-266

Anderson JM, Shive MS (1997) Biodegradation and biocompatibility of PLA and PLGA microspheres. Adv Drug Deliver Rev 28:5-24

Audran R, Peter K, Dannull J, Men Y, Scandella E et al (2003) Encapsulation of peptides in biodegradable microspheres prolongs their MHC class-I presentation by dendritic cells and macrophages in vitro. Vaccine 21:1250-1255

Bailey MM, Berkland CJ (2009) Nanoparticle formulations in pulmonary drug delivery. Med Res Rev 29:196-212

Basheti IA, Obeidat NM, Reddel HK (2017) Effect of novel inhaler technique reminder labels on the retention of inhaler technique skills in asthma: a single-blind randomized controlled trial. NPJ Prim Care Respir Med 27:9

Bhardwaj A, Grobler A, Rath G, Kumar Goyal A, Kumar Jain A et al (2016) Pulmonary delivery of anti-tubercular drugs using ligand anchored $\mathrm{pH}$ sensitive liposomes for the treatment of pulmonary tuberculosis. Curr Drug Deliv 13:909-922

Bilton D, Robinson P, Cooper P, Gallagher C, Kolbe J et al (2011) Inhaled dry powder mannitol in cystic fibrosis: an efficacy and safety study. Eur Respir J 38:1071-1080

Campardelli R, Adami R, Della Porta G, Reverchon E (2012) Nanoparticle precipitation by supercritical assisted injection in a liquid antisolvent. Chem Eng J 192:246-251

Campardelli R, Oleandro E, Reverchon E (2016) Supercritical assisted injection in a liquid antisolvent for PLGA and PLA microparticle production. Powder Technol 287:12-19

Cheow WS, Hadinoto K (2010) Enhancing encapsulation efficiency of highly water-soluble antibiotic in poly (lactic-co-glycolic acid) nanoparticles: modifications of standard nanoparticle preparation methods. Colloids Surf A Physicochem Eng Asp 370:79-86

Cipolla D, Chan H-K (2013) Inhaled antibiotics to treat lung infection. Pharm Pat Anal 2:647-663

Craparo EF, Porsio B, Sardo C, Giammona G, Cavallaro G (2016) Pegylated polyaspartamide-polylactide-based nanoparticles penetrating cystic fibrosis artificial mucus. Biomacromol 17:767-777

d'Angelo I, Casciaro B, Miro A, Quaglia F, Mangoni ML et al (2015) Overcoming barriers in Pseudomonas aeruginosa lung infections: engineered nanoparticles for local delivery of a cationic antimicrobial peptide. Colloids Surf B Biointerfaces 135:717-725

Dailey LA, Schmehl T, Gessler T, Wittmar M, Grimminger F et al (2003) Nebulization of biodegradable nanoparticles: impact of nebulizer technology and nanoparticle characteristics on aerosol features. J Control Release 86:131-144

Debnath SK, Saisivam S, Omri A (2017) PLGA ethionamide nanoparticles for pulmonary delivery: development and in vivo evaluation of dry powder inhaler. J Pharm Biomed Anal 145:854-859

Depreter F, Pilcer G, Amighi K (2013) Inhaled proteins: challenges and perspectives. Int J Pharm 447:251-280

Dewangan HK, Pandey T, Maurya L, Singh S (2018) Rational design and evaluation of HBsAg polymeric nanoparticles as antigen delivery carriers. Int J Biol Macromol 111:804-812

Dutt M, Khuller G (2001) Chemotherapy of mycobacterium tuberculosis infections in mice with a combination of isoniazid and rifampicin entrapped in poly (DL-lactide-co-glycolide) microparticles. J Antimicrob Chemother 47:829-835 
Edwards DA, Ben-Jebria A, Langer R (1998) Recent advances in pulmonary drug delivery using large, porous inhaled particles. J Appl Physiol 85:379-385

Emami F, Vatanara A, Najafabadi AR, Kim Y, Park EJ et al (2018a) Effect of amino acids on the stability of spray freeze-dried immunoglobulin G in sugar-based matrices. Eur J Pharm Sci 119:39-48

Emami F, Vatanara A, Park E, Na D (2018b) Drying technologies for the stability and bioavailability of biopharmaceuticals. Pharmaceutics 10:131

Ernst J, Klinger-Strobel M, Arnold K, Thamm J, Hartung A et al (2018) Polyester-based particles to overcome the obstacles of mucus and biofilms in the lung for tobramycin application under static and dynamic fluidic conditions. Eur J Pharm Biopharm 131:120-129

Faghihi H, Vatanara A, Najafabadi AR, Ramezani V, Gilani K (2014) The use of amino acids to prepare physically and conformationally stable spray-dried IgG with enhanced aerosol performance. Int J Pharm 466:163-171

Fekri Aval S, Akbarzadeh A, Yamchi MR, Zarghami F, Nejati-Koshki $\mathrm{K}$ et al (2016) Gene silencing effect of SiRNA-magnetic modified with biodegradable copolymer nanoparticles on hTERT gene expression in lung cancer cell line. Artif Cells Nanomed Biotechnol 44:188-193

Feng L, Qi XR, Zhou XJ, Maitani Y, Wang SC et al (2006) Pharmaceutical and immunological evaluation of a single-dose hepatitis B vaccine using PLGA microspheres. J Control Release 112:35-42

Gaspar MC, Pais AACC, Sousa JJS, Brillaut J, Olivier JC (2019) Development of levofloxacin-loaded PLGA microspheres of suitable properties for sustained pulmonary release. Int J Pharm 556:117-124

Geller DE, Konstan MW, Smith J, Noonberg SB, Conrad C (2007) Novel tobramycin inhalation powder in cystic fibrosis subjects: pharmacokinetics and safety. Pediatr Pulmonol 42:307-313

Golshahi L, Lynch K, Dennis J, Finlay W (2011) In vitro lung delivery of bacteriophages KS4-M and $\Phi \mathrm{KZ}$ using dry powder inhalers for treatment of Burkholderia cepacia complex and Pseudomonas aeruginosa infections in cystic fibrosis. J Appl Microbiol 110:106-117

Govender T, Stolnik S, Garnett MC, Illum L, Davis SS (1999) PLGA nanoparticles prepared by nanoprecipitation: drug loading and release studies of a water soluble drug. J Control Release 57:171-185

Guo NZ, Zhang Q, Sun Y, Yang HX (2019) Separation and identification of acylated leuprorelin inside PLGA microspheres. Int J Pharm 560:273-281

Gupta V, Ahsan F (2011) Influence of PEI as a core modifying agent on PLGA microspheres of PGE1, a pulmonary selective vasodilator. Int J Pharm 413:51-62

Gupta V, Davis M, Hope-Weeks LJ, Ahsan F (2011) PLGA microparticles encapsulating prostaglandin E1-hydroxypropyl- $\beta$ cyclodextrin (PGE1-HPßCD) complex for the treatment of pulmonary arterial hypertension (PAH). Pharm Res 28:1733-1749

Hang ZL, Ni R, Zhou JY, Mao SR (2015) Recent advances in controlled pulmonary drug delivery. Drug Discov Today 20:380-389

Harush-Frenkel O, Bivas-Benita M, Nassar T, Springer C, Sherman Y et al (2010) A safety and tolerability study of differently-charged nanoparticles for local pulmonary drug delivery. Toxicol Appl Pharmacol 246:83-90

Hillaireau H, Couvreur P (2009) Nanocarriers' entry into the cell: relevance to drug delivery. Cell Mol Life Sci 66:2873-2896

Hitzman CJ, Elmquist WF, Wattenberg LW, Wiedmann TS (2006) Development of a respirable, sustained release microcarrier for 5-fluorouracil I: in vitro assessment of liposomes, microspheres, and lipid coated nanoparticles. J Pharm Sci 95:1114-1126

Holmkvist AD, Friberg A, Nilsson UJ, Schouenborg J (2016) Hydrophobic ion pairing of a minocycline/Ca2 +/AOT complex for preparation of drug-loaded PLGA nanoparticles with improved sustained release. Int J Pharm 499:351-357

Hu X, Yang F-F, Liao Y-H (2016) Pharmacokinetic considerations of inhaled pharmaceuticals for systemic delivery. Curr Pharm Des 22:2532-2548

Hu Y, Li M, Zhang M, Jin Y (2018) Inhalation treatment of idiopathic pulmonary fibrosis with curcumin large porous microparticles. Int J Pharm 551:212-222

Jensen DMK, Cun D, Maltesen MJ, Frokjaer S, Nielsen HM et al (2010) Spray drying of siRNA-containing PLGA nanoparticles intended for inhalation. J Control Release 142:138-145

Ji P, Yu T, Liu Y, Jiang J, Xu J et al (2016) Naringenin-loaded solid lipid nanoparticles: preparation, controlled delivery, cellular uptake, and pulmonary pharmacokinetics. Drug Des Dev Ther 10:911-925

Kanwar MK, Thenappan T, Vachiéry J-L (2016) Update in treatment options in pulmonary hypertension. J Heart Lung Transplant 35:695-703

Kim H, Lee J, Kim TH, Lee ES, Oh KT et al (2011) Albumin-coated porous hollow poly (lactic-co-glycolic acid) microparticles bound with palmityl-acylated exendin- 4 as a long-acting inhalation delivery system for the treatment of diabetes. Pharm Res 28:2008-2019

Kim I, Byeon HJ, Kim TH, Lee ES, Oh KT et al (2012) Doxorubicinloaded highly porous large PLGA microparticles as a sustainedrelease inhalation system for the treatment of metastatic lung cancer. Biomaterials 33:5574-5583

Kim I, Byeon HJ, Kim TH, Lee ES, Oh KT et al (2013) Doxorubicinloaded porous PLGA microparticles with surface attached TRAIL for the inhalation treatment of metastatic lung cancer. Biomaterials 34:6444-6453

Kolte A, Patil S, Lesimple P, Hanrahan JW, Misra A (2017) PEGylated composite nanoparticles of PLGA and polyethylenimine for safe and efficient delivery of pDNA to lungs. Int J Pharm 524:382-396

Kumari A, Yadav SK, Yadav SC (2010) Biodegradable polymeric nanoparticles based drug delivery systems. Colloids Surf B Biointerfaces 75:1-18

Labiris N, Dolovich M (2003a) Pulmonary drug delivery. Part I: physiological factors affecting therapeutic effectiveness of aerosolized medications. Br J Clin Pharmacol 56:588-599

Labiris NR, Dolovich MB (2003b) Pulmonary drug delivery. Part II: the role of inhalant delivery devices and drug formulations in therapeutic effectiveness of aerosolized medications. Br J Clin Pharmacol 56:600-612

Lai SK, Wang YY, Hanes J (2009) Mucus-penetrating nanoparticles for drug and gene delivery to mucosal tissues. Adv Drug Deliv Rev 61:158-171

Lavorini F, Magnan A, Dubus JC, Voshaar T, Corbetta L et al (2008) Effect of incorrect use of dry powder inhalers on management of patients with asthma and COPD. Respir Med 102:593-604

Lee BK, Yun Y, Park K (2016) PLA micro-and nano-particles. Adv Drug Deliver Rev 107:176-191

Lee H-G, Kim D-W, Park C-W (2018) Dry powder inhaler for pulmonary drug delivery: human respiratory system, approved products and therapeutic equivalence guideline. J Pharm Investig 48:603-616

Liu Z, Li X, Xiu B, Duan C, Li J et al (2016) A novel and simple preparative method for uniform-sized PLGA microspheres: preliminary application in antitubercular drug delivery. Colloids Surf B Biointerfaces 145:679-687

Lu D, Garcia-Contreras L, Xu D, Kurtz SL, Liu J et al (2007) Poly (lactide-co-glycolide) microspheres in respirable sizes enhance an in vitro $\mathrm{T}$ cell response to recombinant Mycobacterium tuberculosis antigen 85B. Pharm Res 24:1834-1843 
Mahajan HS, Mahajan PR (2016) Development of grafted xyloglucan micelles for pulmonary delivery of curcumin: in vitro and in vivo studies. Int J Biol Macromol 82:621-627

Men Y, Audran R, Thomasin C, Eberl G, Demotz S et al (1999) MHC class I-and class II-restricted processing and presentation of microencapsulated antigens. Vaccine 17:1047-1056

Menon JU, Ravikumar P, Pise A, Gyawali D, Hsia CC et al (2014) Polymeric nanoparticles for pulmonary protein and DNA delivery. Acta Biomater 10:2643-2652

Mohamed F, van der Walle CF (2006) PLGA microcapsules with novel dimpled surfaces for pulmonary delivery of DNA. Int $\mathbf{J}$ Pharm 311:97-107

Mohamed F, van der Walle CF (2008) Engineering biodegradable polyester particles with specific drug targeting and drug release properties. J Pharm Sci 97:71-87

Moroz E, Matoori S, Leroux J-C (2016) Oral delivery of macromolecular drugs: where we are after almost 100 years of attempts. Adv Drug Deliv Rev 101:108-121

Mundargi RC, Babu VR, Rangaswamy V, Patel P, Aminabhavi TM (2008) Nano/micro technologies for delivering macromolecular therapeutics using poly (D,L-lactide-co-glycolide) and its derivatives. J Control Release 125:193-209

Muttil P, Kaur J, Kumar K, Yadav AB, Sharma R et al (2007) Inhalable microparticles containing large payload of anti-tuberculosis drugs. Eur J Pharm Sci 32:140-150

Na DH, DeLuca PP (2005) PEGylation of octreotide: i. Separation of positional isomers and stability against acylation by poly (D,L-lactide-co-glycolide). Pharm Res 22:736-742

Na DH, Youn YS, Lee SD, Son MW, Kim WB et al (2003) Monitoring of peptide acylation inside degrading PLGA microspheres by capillary electrophoresis and MALDI-TOF mass spectrometry. J Control Release 92:291-299

$\mathrm{Na}$ DH, Lee JE, Jang SW, Lee KC (2007) Formation of acylated growth hormone-releasing peptide- 6 by poly (lactide-co-glycolide) and its biological activity. AAPS PharmSciTech 8:E105-E109

Nandiyanto ABD, Okuyama K (2011) Progress in developing spraydrying methods for the production of controlled morphology particles: from the nanometer to submicrometer size ranges. Adv Powder Technol 22:1-19

Ni R, Muenster U, Zhao J, Zhang L, Becker-Pelster E-M et al (2017) Exploring polyvinylpyrrolidone in the engineering of large porous PLGA microparticles via single emulsion method with tunable sustained release in the lung: in vitro and in vivo characterization. J Control Release 249:11-22

Nishimura S, Takami T, Murakami Y (2017) Porous PLGA microparticles formed by "one-step" emulsification for pulmonary drug delivery: the surface morphology and the aerodynamic properties. Colloids Surfaces B Biointerfaces 159:318-326

Oh YJ, Lee J, Seo JY, Rhim T, Kim S-H et al (2011) Preparation of budesonide-loaded porous PLGA microparticles and their therapeutic efficacy in a murine asthma model. J Control Release 150:56-62

O'Hagan DT, Singh M, Gupta RK (1998) Poly (lactide-co-glycolide) microparticles for the development of single-dose controlledrelease vaccines. Adv Drug Deliv Rev 32:225-246

Ohashi K, Kabasawa T, Ozeki T, Okada H (2009) One-step preparation of rifampicin/poly (lactic-co-glycolic acid) nanoparticlecontaining mannitol microspheres using a four-fluid nozzle spray drier for inhalation therapy of tuberculosis. J Control Release 135:19-24

Oliveira PM, Matos BN, Pereira PA, Gratieri T, Faccioli LH et al (2017) Microparticles prepared with 50-190 kDa chitosan as promising non-toxic carriers for pulmonary delivery of isoniazid. Carbohydr Polym 174:421-431
Panyam J, Labhasetwar V (2003) Biodegradable nanoparticles for drug and gene delivery to cells and tissue. Adv Drug Deliv Rev 55:329-347

Paranjpe M, Muller-Goymann CC (2014) Nanoparticle-mediated pulmonary drug delivery: a review. Int J Mol Sci 15:5852-5873

Park EJ, Na DH, Lee KC (2007) In vitro release study of monoPEGylated growth hormone-releasing peptide- 6 from PLGA microspheres. Int J Pharm 343:281-283

Parumasivam T, Leung SS, Quan DH, Triccas JA, Britton WJ et al (2016) Rifapentine-loaded PLGA microparticles for tuberculosis inhaled therapy: preparation and in vitro aerosol characterization. Eur J Pharm Sci 88:1-11

Patel B, Rashid J, Ahsan F (2017a) Aerosolizable modified-release particles of montelukast improve retention and availability of the drug in the lungs. Eur J Pharm Sci 96:560-570

Patel B, Rashid J, Gupta N, Ahsan F (2017b) Low-molecular-weight heparin-coated and montelukast-filled inhalable particles: a dual-drug delivery system for combination therapy in asthma. J Pharm Sci 106:1124-1135

Patil J, Sarasija S (2012) Pulmonary drug delivery strategies: a concise, systematic review. Lung India: Off Organ Indian Chest Soc 29:44

Patton JS, Byron PR (2007) Inhaling medicines: delivering drugs to the body through the lungs. Nat Rev Drug Discov 6:67-74

Pison U, Welte T, Giersig M, Groneberg DA (2006) Nanomedicine for respiratory diseases. Eur J Pharmacol 533:341-350

Poursina N, Vatanara A, Rouini MR, Gilani K, Najafabadi AR (2016) The effect of excipients on the stability and aerosol performance of salmon calcitonin dry powder inhalers prepared via spray freeze drying process. Acta Pharm 66:207-218

Priemel PA, Wang Y, Bohr A, Water JJ, Yang M et al (2018) Poly (ethylene carbonate)-containing polylactic acid microparticles with rifampicin improve drug delivery to macrophages. J Pharm Pharmacol 70:1009-1021

Ramezani V, Vatanara A, Najafabadi AR, Gilani K, Nabi-Meybodi M (2013) Screening and evaluation of variables in the formation of antibody particles by spray drying. Powder Technol 233:341-346

Ramezani V, Vatanara A, Najafabadi AR, Shokrgozar MA, Khabiri A et al (2014) A comparative study on the physicochemical and biological stability of IgG 1 and monoclonal antibodies during spray drying process. DARU J Pharm Sci 22:31

Rashid J, Alobaida A, Al-Hilal TA, Hammouda S, McMurtry IF et al (2018) Repurposing rosiglitazone, a PPAR- $\gamma$ agonist and oral antidiabetic, as an inhaled formulation, for the treatment of PAH. J Control Release 280:113-123

Rogueda PGA, Traini D (2007) The nanoscale in pulmonary delivery. Part 1: deposition, fate, toxicology and effects. Expert Opin Drug Del 4:595-606

Ruge CA, Hillaireau H, Ng Grabowski, Beck-Broichsitter M, Cañadas O et al (2016) Pulmonary surfactant protein A-mediated enrichment of surface-decorated polymeric nanoparticles in alveolar macrophages. Mol Pharm 13:4168-4178

Rytting E, Nguyen J, Wang X, Kissel T (2008) Biodegradable polymeric nanocarriers for pulmonary drug delivery. Expert Opin Drug Deliv 5:629-639

Saini V, Jain V, Sudheesh MS, Jaganathan KS, Murthy PK et al (2011) Comparison of humoral and cell-mediated immune responses to cationic PLGA microspheres containing recombinant hepatitis B antigen. Int J Pharm 408:50-57

Schoubben A, Blasi P, Giovagnoli S, Ricci M, Rossi C (2010) Simple and scalable method for peptide inhalable powder production. Eur J Pharm Sci 39:53-58

Schulte M, Osseiran K, Betz R, Wencker M, Brand P et al (2008) Handling of and preferences for available dry powder inhaler systems by patients with asthma and COPD. J Aerosol Med Pulm Drug Deliv 21:321-328 
Seydoux E, Rodriguez-Lorenzo L, Blom RA, Stumbles PA, Petri-Fink A et al (2016) Pulmonary delivery of cationic gold nanoparticles boost antigen-specific CD4 $+\mathrm{T}$ cell proliferation. Nanomedicine 12:1815-1826

Sham JOH, Zhang Y, Finlay WH, Roa WH, Lobenberg R (2004) Formulation and characterization of spray-dried powders containing nanoparticles for aerosol delivery to the lung. Int J Pharm 269:457-467

Shi X, Li C, Gao S, Zhang L, Han H et al (2014) Combination of doxorubicin-based chemotherapy and polyethylenimine/p53 gene therapy for the treatment of lung cancer using porous PLGA microparticles. Colloids Surf B Biointerfaces 122:498-504

Shirangi M, Hennink WE, Somsen GW, van Nostrum CF (2016) Acylation of arginine in goserelin-loaded PLGA microspheres. Eur J Pharm Biopharm 99:18-23

Shire SJ, Shahrokh Z, Liu J (2004) Challenges in the development of high protein concentration formulations. J Pharm Sci 93:1390-1402

Shirley M (2019) Amikacin liposome inhalation suspension: a review in Mycobacterium avium complex lung disease. Drugs 79:555-562

Song JG, Lee SH, Han H-K (2017) The stabilization of biopharmaceuticals: current understanding and future perspectives. J Pharm Investig 47:475-496

Sulaiman I, Cushen B, Greene G, Seheult J, Seow D et al (2017) Objective assessment of adherence to inhalers by patients with chronic obstructive pulmonary disease. Am J Respir Crit Care Med 195:1333-1343

Sung JC, Pulliam BL, Edwards DA (2007) Nanoparticles for drug delivery to the lungs. Trends Biotechnol 25:563-570

Takeuchi I, Tetsuka Y, Nii T, Shinogase M, Makino K (2017) Inhalable nanocomposite particles using amino acids with improved drug content and humidity resistance. Colloids Surf A Physicochem Eng Asp 529:387-393

Tavares M, Cabral RP, Costa C, Martins P, Fernandes AR et al (2017) Development of PLGA dry powder microparticles by supercritical CO2-assisted spray-drying for potential vaccine delivery to the lungs. J Supercrit Fluids 128:235-243

Thwala LN, Préat V, Csaba NS (2017) Emerging delivery platforms for mucosal administration of biopharmaceuticals: a critical update on nasal, pulmonary and oral routes. Expert Opin Drug Deliv $14: 23-36$

Türeli NG, Türeli AE, Schneider M (2016) Optimization of ciprofloxacin complex loaded PLGA nanoparticles for pulmonary treatment of cystic fibrosis infections: design of experiments approach. Int J Pharm 515:343-351
Türeli NG, Torge A, Juntke J, Schwarz BC, Schneider-Daum N et al (2017) Ciprofloxacin-loaded PLGA nanoparticles against cystic fibrosis P. aeruginosa lung infections. Eur J Pharm Biopharm 117:363-371

Tyler B, Gullotti D, Mangraviti A, Utsuki T, Brem H (2016) Polylactic acid (PLA) controlled delivery carriers for biomedical applications. Adv Drug Deliv Rev 107:163-175

Ungaro F, De Rosa G, Miro A, Quaglia F, La Rotonda MI (2006) Cyclodextrins in the production of large porous particles: development of dry powders for the sustained release of insulin to the lungs. Eur J Pharm Sci 28:423-432

Ungaro F, d'Angelo I, Miro A, La Rotonda MI, Quaglia F (2012) Engineered PLGA nano- and micro-carriers for pulmonary delivery: challenges and promises. J Pharm Pharmacol 64:1217-1235

Vordermeier H, Coombes A, Jenkins P, McGee J, O'Hagan D et al (1995) Synthetic delivery system for tuberculosis vaccines: immunological evaluation of the $\mathrm{M}$. tuberculosis $38 \mathrm{kDa}$ protein entrapped in biodegradable PLG microparticles. Vaccine 13:1576-1582

Wu D, Wang C, Yang J, Wang H, Han H et al (2016) Improving the intracellular drug concentration in lung cancer treatment through the codelivery of doxorubicin and miR-519c mediated by porous PLGA microparticle. Mol Pharm 13:3925-3933

Yamamoto H, Kuno Y, Sugimoto S, Takeuchi H, Kawashima Y (2005) Surface-modified PLGA nanosphere with chitosan improved pulmonary delivery of calcitonin by mucoadhesion and opening of the intercellular tight junctions. J Control Release 102:373-381

Yamamoto H, Hoshina W, Kurashima H, Takeuchi H, Kawashima Y et al (2007) Engineering of poly (DL-lactic-co-glycolic acid) nanocomposite particles for dry powder inhalation dosage forms of insulin with the spray-fluidized bed granulating system. Adv Powder Technol 18:215-228

Yang W, Peters JI, Williams RO (2008) Inhaled nanoparticles-a current review. Int J Pharmaceut 356:239-247

Yang Y, Bajaj N, Xu P, Ohn K, Tsifansky MD et al (2009) Development of highly porous large PLGA microparticles for pulmonary drug delivery. Biomaterials 30:1947-1953

Yu M, Wu J, Shi J, Farokhzad OC (2016) Nanotechnology for protein delivery: overview and perspectives. J Control Release 240:24-37

Zhu L, Li M, Liu X, Jin Y (2017) Drug-loaded PLGA electrospraying porous microspheres for the local therapy of primary lung cancer via pulmonary delivery. ACS Omega 2:2273-2279

Publisher's Note Springer Nature remains neutral with regard to jurisdictional claims in published maps and institutional affiliations. 